\title{
Euschistus heros mass rearing technique for the multiplication of Telenomus podisi
}

\author{
Cleonor Cavalcante Silva(1), Raul Alberto Laumann ${ }^{(1)}$, Maria Carolina Blassioli(l), \\ Martin Pareja ${ }^{(2)}$ and Miguel Borges ${ }^{(1)}$
}

\begin{abstract}
(1)Embrapa Recursos Genéticos e Biotecnologia, Caixa Postal 02372, CEP 70770-900 Brasília, DF, Brazil. E-mail: cleonor@cenargen.embrapa.br, laumann@cenargen.embrapa.br, mcbmorae@cenargen.embrapa.br, mborges@cenargen.embrapa.br (2)Swedish University of Agricultural Sciences, Department of Ecology - SLU PO Box 7044 Se 750 07, Uppsala, Sweden. E mail: martinpareja@googlemail.com
\end{abstract}

\begin{abstract}
The objective of this work was to improve the mass rearing technique of Euschistus heros in laboratory. Nymphs and adults were reared at densities 100, 200,300 and 400 eggs per Petri dish (9 cm diameter), and at 50, 100,150 and 200 couples per rearing cages $(900 \mathrm{~mL})$, respectively. Survival rate of immature stages and survivorship and reproduction of adults were determinated. Survivorship of nymph to adult was the highest (89\%) at density 100 eggs per dish. Adult survivorship was independent of density, and 100 couples per cage were the best to improve quality of the produced progeny. In these conditions, fecundity was $160.8 \pm 9.28$ eggs per female, and a total of $8,950 \pm 456$ eggs per cage per month was produced. Two hundred couples per cage showed a negative effect on reproduction, which decreased to $65 \%$. With this technique, a colony of 35 cages with 100 couples per cage yields about 313.3 thousands eggs per month, which is enough to supply the egg parasitoid Telenomus podisi to colonize about 35 ha of soybean field.
\end{abstract}

Index terms: biological control, density, egg parasitoid, neotropical brown stink bug.

\section{Técnica de criação massal de Euschistus heros para a multiplicação de Telenomus podisi}

\begin{abstract}
Resumo - O objetivo deste trabalho foi melhorar a técnica de criação massal de Euschistus heros em laboratório. Ninfas e adultos foram criados nas densidades de 100, 200, 300 e 400 ovos por placa de Petri ( 9 cm diâmetro), e 50, 100,150 e 200 casais por gaiola de criação $(900 \mathrm{~mL})$, respectivamente. Foram determinadas a taxa de sobrevivência dos estágios imaturos e a sobrevivência e reprodução de adultos. A sobrevivência das ninfas até o estágio de adulto foi maior ( $89 \%$ ) quando criadas em densidade de 100 ovos por placa de Petri. A sobrevivência dos adultos foi independente da densidade, e 100 casais por gaiola de criação foi a melhor densidade encontrada para melhorar a qualidade dos insetos. Nessas condições, a fecundidade das fêmeas foi de 160,8 $\pm 9,28$ ovos por fêmea, e um total de $8.950 \pm 456$ ovos por gaiola por mês foi produzido. A densidade de 200 casais por gaiola apresentou efeito negativo sobre a reprodução, que decresceu $65 \%$. Com esta técnica, uma colônia de 35 gaiolas com 100 casais por gaiola produz cerca de 313,3 mil ovos por mês, quantidade suficiente para liberar o parasitóide de ovos Telenomus podisi em 35 ha de plantio de soja.
\end{abstract}

Termos para indexação: controle biológico, densidade, parasitóide de ovos, percevejo marrom.

\section{Introduction}

The Neotropical brown stink bug, Euschistus heros (F.) (Hemiptera: Pentatomidae) is the most abundant component of the stink bugs complex that are pests of soybean (Panizzi \& Oliveira, 1998), particularly in the Central-West and Northeast regions, in Brazil, where the climate is warmer (Cividanes \& Parra, 1994). The population levels begin to increase after the emergence of overwintering adults, and outbreaks of bugs are usually controlled with nonselective pesticides (Panizzi \& Vivan,
1997), which have led to the development of resistant populations (Sosa-Gomez et al., 2001).

The use of egg parasitoids (Scelionidae) to control the stink bugs pest of soybean has proved to be effective in classical (Caltagirone, 1981; Clarke, 1990; Ehler, 2002) and inoculative (Corrêa-Ferreira, 2002) biological control strategies. In the northern areas of Paraná State, Brazil, efforts were made to control the southern green stink bug Nezara viridula (L.) (Hemiptera: Pentatomidae) through inoculative liberations of Trissolcus basalis (Wollaston) (Hymenoptera: Scelionidae) (Corrêa- 
Ferreira \& Moscardi, 1996). However, this strategy is not available for extensive areas, due to difficulties in obtaining high numbers of the parasitoid, which depend on egg production of its preferred host, $N$. viridula. With the increasing population of $E$. heros in soybean fields, this species is a good alternative host for mass rearing of T. basalis (Peres \& Corrêa-Ferreira, 2001). In addition, E. heros is the preferred host of Telenomus podisi (Ashmead) (Hymenoptera: Scelionidae), another egg parasitoid of the bugs (Corrêa-Ferreira \& Moscardi, 1995; Sujii et al., 2002).

Attempts to rear E. heros on artificial diets resulted in partial success. Elongation of nymph developmental time and low rate of oviposition were observed, when compared to insects reared on natural diets (Panizzi et al., 2000; Fortes et al., 2006).

Research on E. heros chemical communication has become increasingly important, after the findings that the male bug produces sex pheromone, which has potential for controlling the pest (Borges et al., 1999, 2003). Colonies of the bug have been established for collection of pheromones, production of T. podisi and studies in foraging behavior (Sujii et al., 2002; Borges et al., 2003; Silva et al., 2006). Such studies, however, require a sufficient amount of high quality insects, at specified time and at specific stages of development. To achieve these requirements, the rearing technique of the bug has to be optimized. In the laboratory of Ecology and Semiochemicals of Embrapa Recursos Genéticos e Biotecnologia, a colony of $E$. heros has been maintained on natural diet for nearly 15 years. The main problem, facing while increasing the colony, was the high population inside the cages and the lack of information about the optimal density to improve the quality and egg production of the insects.

The objective of this work was to improve the mass rearing technique for $E$. heros in laboratory.

\section{Materials and Methods}

Adults of E. heros were reared in transparent plastic containers of $900 \mathrm{~mL}$ (40 cages) and fed with: fresh green bean pods - Phaseolus vulgaris L.; dry soybean seeds - Glycine $\max$ L.; raw shelled peanuts - Arachis hypogaea L.; sunflower seeds - Helianthus annuus L.; and water, renewed twice a week when cages were replaced. Nylon mesh screens $\left(15 \mathrm{~cm}^{2}\right)$, placed inside the cages, provided additional area for oviposition and walking (eggs were laid on the pods and on the nylon screens). Cages were covered with a fine mesh cloth for ventilation, and placed in an climate room at $26 \pm 1^{\circ} \mathrm{C}, 60 \pm 10 \% \mathrm{RH}$ and photofase of $14: 10$ hours light:dark. Every two days, approximately 400 eggs were collected and placed in $9 \times 2 \mathrm{~cm}$ plastic Petri dishes, lined with filter paper together with a piece of fresh green bean pod to add moisture. Until the end of the third instar, nymphs were reared in Petri dishes and fed with pieces of green bean pods, raw shelled peanuts and sunflower seeds. When started molting to the fourth instar, they were transferred to cages for complete development. This is the conventional way of rearing this bug in stock colony.

Eggs less than 24 hours old were collected from the stock colony and placed in Petri dishes at the densities of 100, 200, 300 and 400 eggs per dish, with nine replicates $(1$ dish $=1$ replication $)$; the dishes were examined daily for egg hatching, molting and mortality of nymphs. When nymphs reached the third instar, three replicates of each treatment were pooled and transferred to adult cages. Survival rate of immature stages was determined in the stages egg to first instar, first to third instar, and third instar to adult stage. Experimental conditions were the same as those for the stock colony. Pooled data (normally distributed) were analyzed by oneway ANOVA, followed by a Student-Newman-Keuls test, at $5 \%$ of probability, in order to determine differences among treatments. Chi-square test, at 5\% of probability, was used to compare sex ratio.

The survivorship and reproduction of $E$. heros females was observed at the densities of 50,100, 150, and 200 couples per cage, with five replicates. Newly molted adults were taken from the colony and confined in rearing cages. To determine the effects of densities on female fecundity and survival, each cage was observed each morning, for removal of eggs laid in the previous night and counting of dead females. Egg masses collected from each cage were weighted, and total number of eggs was estimated using mean weight of 100 eggs (43.20 $\pm 1.07 \mathrm{mg}, \mathrm{N}=6$ ). Daily fecundity was calculated by dividing the total number of eggs by the total number of females alive in each cage on that day. Dead adults were not replaced. Egg production per cage at each density was recorded during 35 days. Survivorship curves were plotted by calculating the percentage of females survival. Significant differences among treatments were calculated using one-way ANOVA and Student-Newman-Keuls test, at $5 \%$ of probability. 
Based on the results of female survivorship and reproduction, the density of 100 couple per cage was the best condition for egg production in the colony, and for establishing the improved technique in the laboratory. Every ten days, over a period of 2.5 months, newly molted old adults were separated, and placed in a set of five cages with 100 couples per cage. Eggs produced were collected daily from each cage, and its total number was estimated using egg weight procedure described. Eggs were used to rear the egg parasitoid T. podisi, and the remaining ones were weighted again and used in laboratory experiments, and to maintain the colony. Adults were kept in cages until they reached 35 days and were, then, eliminated.

\section{Results and Discussion}

In all treatments, hatching of eggs was asynchronous, occurring over a period of four to six days (5.6 \pm 1.17$)$. Density of eggs per Petri dish significantly affected nymphs survivorship (eggs to first instar nymphs, $\mathrm{F}=24.65, \mathrm{df}=3,34, \mathrm{p}<0.05$; first instar to third instar nymphs, $\mathrm{F}=12.43$, $\mathrm{df}=3,34, \mathrm{p}>0.05$; third instar nymphs to adult, $\mathrm{F}=12.20, \mathrm{df}=3,10, \mathrm{p}<0.05$ ) (Table 1). At density of 100 or 200 eggs per Petri dish, the survival rate from eggs to first instar nymphs and from first instar to third instar nymphs was higher (SNK test, $\mathrm{p}<0.05$ ) when compared to other treatments. Similarly, the survivorship of third instar nymphs to adult stage was higher than insects reared at higher densities (SNK test, $\mathrm{p}<0.05)$. Densities of 300 and 400 eggs per Petri dish caused a mean reduction of $43 \%$ in the number of nymphs reaching the adult stage, probably due to competition for resources. For many insect species, optimal density among juveniles depends on the number and distribution of eggs (Sato et al., 2004), and high density produces high mortality, due to intraspecific competition for resources (Moe et al., 2002; Sato et al., 2004; Bauerfeind et al., 2005). There was no significant effect of density on adult sex ratio (Table 1).

Adult density significantly affected female fecundity and reproduction (Table 2). A similar trend of oviposition among different densities was observed (Figure 1). In all densities, oviposition started with high numbers (6.3 eggs per female), and then decreased gradually from the third week (about 25 days old) to lower levels (3.42 eggs per female), with small rises as females increased in age or died. Maximum egg oviposition was 11 eggs per female per day, and number of eggs laid varied from 907 to 1,811 for all five cages. Egg production

Table 1. Survival rates of Euschistus heros nymphs and adults reared in laboratory at different densities $\left(26 \pm 1^{\circ} \mathrm{C}, \mathrm{RH} 60 \pm 10 \%\right.$, photophase of 14 hours $)^{(1)}$.

\begin{tabular}{|c|c|c|c|c|c|}
\hline $\begin{array}{c}\text { Number of eggs } \\
\text { per Petri dish }\end{array}$ & $\begin{array}{c}\text { Egg }-1^{\text {st }} \text { instar } \\
\text { nymphs }\end{array}$ & $\begin{array}{c}1^{\text {st }}-3^{\text {rd }} \text { instar } \\
\text { nymphs }\end{array}$ & $3^{\text {rd }}$ instar - adults $^{(2)}$ & Males & Females \\
\hline 100 & $\begin{array}{c}80.33 \pm 2.69 a \\
(\mathrm{n}=723)\end{array}$ & $\begin{array}{c}69.22 \pm 2.32 \mathrm{a} \\
(\mathrm{n}=581)\end{array}$ & $\begin{array}{c}88.70 \pm 4.64 \mathrm{a} \\
(\mathrm{n}=520)\end{array}$ & $\begin{array}{c}48.46 \pm 0.96 \\
(\mathrm{n}=257)\end{array}$ & $\begin{array}{c}51.54 \pm 0.97 \\
(\mathrm{n}=263)\end{array}$ \\
\hline 200 & $\begin{array}{c}74.61 \pm 2.03 \mathrm{a} \\
(\mathrm{n}=1,349)\end{array}$ & $\begin{array}{c}74.25 \pm 2.74 \mathrm{a} \\
(\mathrm{n}=965)\end{array}$ & $\begin{array}{c}51.37 \pm 4.33 \mathrm{~b} \\
(\mathrm{n}=506)\end{array}$ & $\begin{array}{c}50.33 \pm 0.88 \\
(\mathrm{n}=259)\end{array}$ & $\begin{array}{c}49.33 \pm 0.99 \\
(\mathrm{n}=247)\end{array}$ \\
\hline 300 & $\begin{array}{c}58.65 \pm 1.83 \mathrm{~b} \\
(\mathrm{n}=1,599)\end{array}$ & $\begin{array}{c}56.79 \pm 3.63 b \\
(n=958)\end{array}$ & $\begin{array}{c}42.54 \pm 4.28 \mathrm{bc} \\
(\mathrm{n}=402)\end{array}$ & $\begin{array}{c}52.92 \pm 1.15 \\
(\mathrm{n}=213)\end{array}$ & $\begin{array}{c}47.08 \pm 1.15 \\
(\mathrm{n}=189)\end{array}$ \\
\hline 400 & $\begin{array}{c}55.61 \pm 2.99 \mathrm{~b} \\
(\mathrm{n}=2,002)\end{array}$ & $\begin{array}{c}46.74 \pm 4.85 \mathrm{c} \\
(\mathrm{n}=936)\end{array}$ & $\begin{array}{c}43.22 \pm 9.92 \mathrm{c} \\
(\mathrm{n}=363)\end{array}$ & $\begin{array}{c}53.54 \pm 1.51 \\
(\mathrm{n}=196)\end{array}$ & $\begin{array}{c}46.46 \pm 1.51 \\
(\mathrm{n}=167)\end{array}$ \\
\hline
\end{tabular}

${ }^{(1)}$ Means of nine replicates \pm SEM followed by equal letters do not differ by the test of Student-Newman-Keuls and chi-square test (for sex rate), both at $5 \%$ of probability, for sex rate; values in parentheses indicate the number of individuals. ${ }^{(2)}$ Nymphs were transferred to adult cages.

Table 2. Reproductive performance of Euschistus heros female reared at different densities in laboratory $\left(26 \pm 1^{\circ} \mathrm{C}, \mathrm{RH} 60 \pm 10 \%\right.$, photophase of 14 hours $)^{(1)}$.

\begin{tabular}{ccccc}
\hline $\begin{array}{c}\text { Number of couples } \\
\text { per cage }\end{array}$ & $\begin{array}{c}\text { Number of eggs per } \\
\text { female per day }\end{array}$ & $\begin{array}{c}\text { Number of eggs per } \\
\text { female }\end{array}$ & $\begin{array}{c}\text { Number of eggs per cage } \\
\text { per day }\end{array}$ & $\begin{array}{c}\text { Total number of eggs } \\
\text { per cage }\end{array}$ \\
\hline 50 & $6.49 \pm 0.31 \mathrm{a}$ & $175.23 \pm 8.34 \mathrm{a}$ & $181.35 \pm 16.06 \mathrm{a}$ & $4,896.51 \pm 433.69 \mathrm{a}$ \\
100 & $6.22 \pm 0.36 \mathrm{a}$ & $160.76 \pm 9.28 \mathrm{a}$ & $344.26 \pm 17.56 \mathrm{~b}$ & $8,950.73 \pm 456.44 \mathrm{~b}$ \\
150 & $4.81 \pm 0.29 \mathrm{~b}$ & $129.02 \pm 8.391 \mathrm{~b}$ & $353.10 \pm 18.75 \mathrm{bc}$ & $9,533.56 \pm 506.37 \mathrm{bc}$ \\
200 & $4.39 \pm 0.12 \mathrm{~b}$ & $114.04 \pm 3.21 \mathrm{~b}$ & $420.98 \pm 10.54 \mathrm{bc}$ & $10,681.65 \pm 283.81 \mathrm{c}$ \\
\hline
\end{tabular}

${ }^{(1)}$ Means of five replicates \pm SEM followed by equal letters do not differ by Student-Newman-Keuls test, at $5 \%$ of probability; the experiment was conducted for five consecutive weeks; dead females were not replaced during the experiment. 
peaked between the $13^{\text {th }}$ and $23^{\text {rd }}$ day of oviposition (Figure 1).

Although there was a difference in the proportion of females dying, during the first four days, when reared at the density 200 couples per cage, adult survivorship was not affected by adult density used. The pattern of survivorship curves suggests that mortality occurred independent of age (Figure 1). Peres \& Corrêa-Ferreira (2001) reared E. heros in cages $(50 \times 50 \times 70 \mathrm{~cm})$ with 100 couples, and reported a similar survival curve.

Comparing the daily fecundity (number of eggs/ female/day) of females reared at different densities, a significant difference was observed between the oviposition by females reared at 50 and 100 couples per cage and those reared at 150 and 200 couples per cage $(\mathrm{F}=13.36, \mathrm{df}=3,18, \mathrm{p}<0.05, \mathrm{SNK}$ test $\mathrm{p}<0.05)$ (Table 2). Similarly, total fecundity (number of eggs/ female) was significantly higher, when compared to females reared at high densities $(\mathrm{F}=13.40, \mathrm{df}=3,18$,
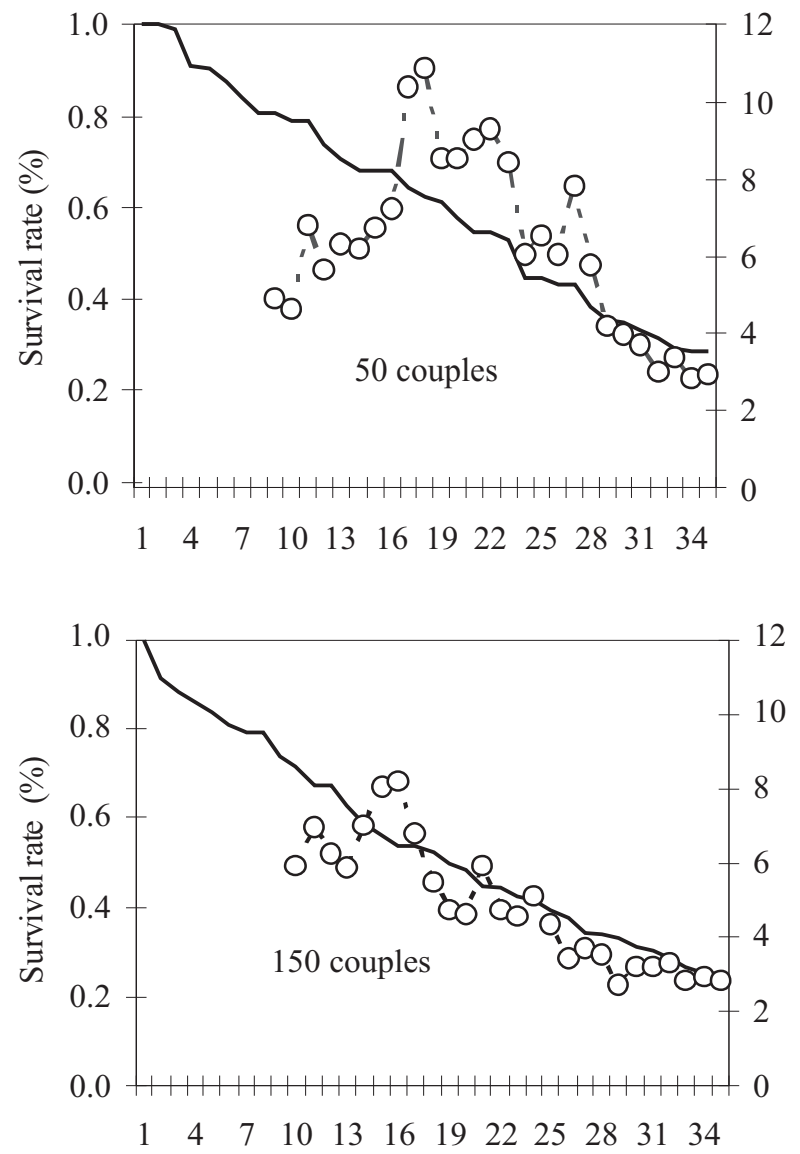

Days after emergence $\mathrm{p}<0.05$ ). Although egg production (number of eggs/cage/ day and total eggs/cage) was higher at the densities of 150 and 200 couples per cage $(\mathrm{F}=40.18$ and $\mathrm{F}=34.57$, $\mathrm{df}=3,18, \mathrm{p}<0.05$, SNK test $\mathrm{p}<0.05$, respectively), the increase in these parameters was not directly proportional to the increase in females into the rearing cages. These data indicate a negative effect of high density on female reproduction (adult density declined during the experiment, and females tended to deposit 1.4 less eggs per day), and support the general explanation that reproduction is directly dependent on adult density (Bauerfeind \& Fischer, 2005). The reduced fecundity of females may be due to competition for oviposition site or for mating encounter. Costa et al. (1998) reported that E. heros females that mated more often produced more eggs than those mated only once.

It was not observed significant difference in individual female fecundity between females from densities 50 and 100 couples per cage; however, to obtain an egg
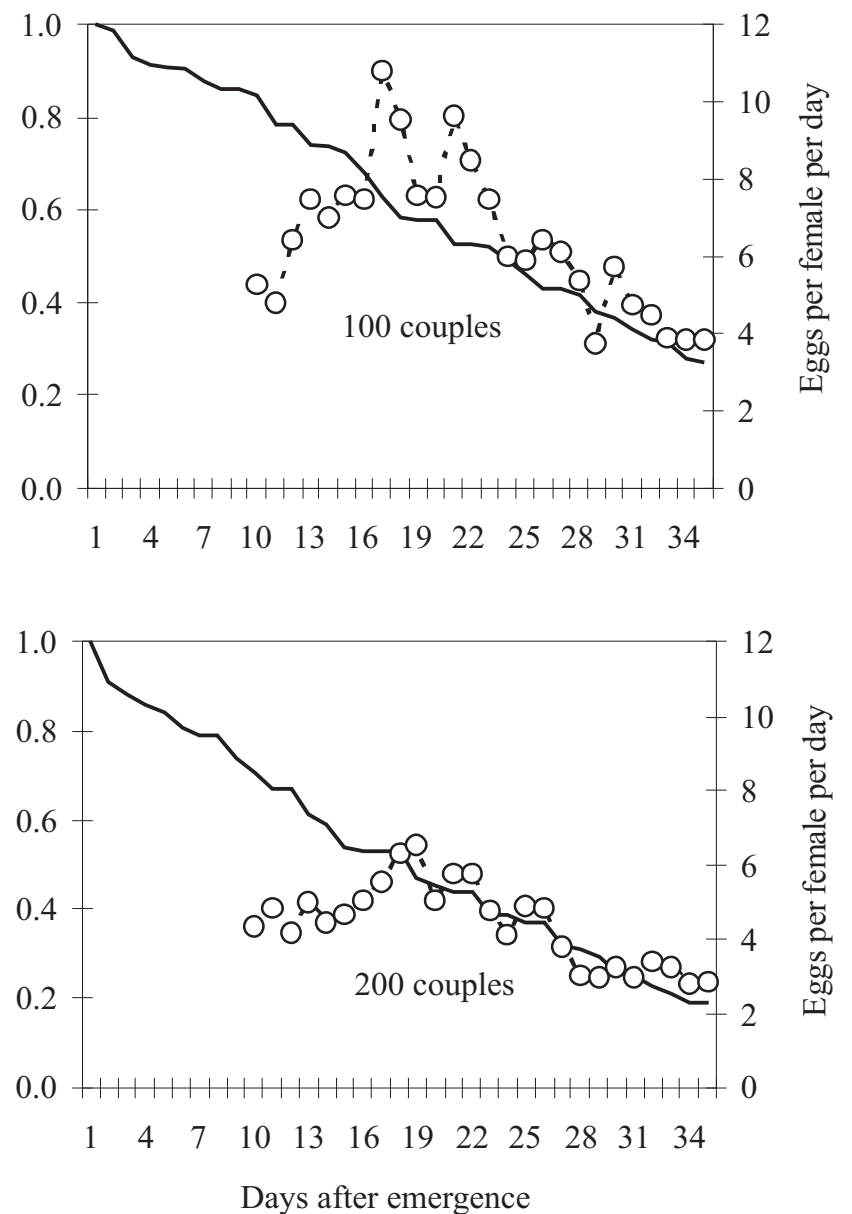

Figure 1. Survivorship (line) and daily fecundity (open circle) curves of Euschistus heros females, up to 35 days after emergency, reared at 50, 100, 150 and 200 couples per cage in laboratory $\left(26 \pm 1{ }^{\circ} \mathrm{C}, 60 \pm 10 \% \mathrm{RH}\right.$ and photophase of 14 hours). 
production similar to 100 couples, working with 50 couples, it is necessary to increase the number of cages by a factor of 1.6, with a corresponding increase in handling time, space and materials. Therefore, 100 couples per cage were considered the optimal density. Peres \& Corrêa-Ferreira (2001) reared E. heros in identical density, and reported a mean of 809 and 744 eggs per cage $(50 \times 50 \times 70 \mathrm{~cm})$, during the peak of oviposition, and a total of 5,547 eggs per cage, similar to the results obtained in the present work. Their methodology, however, using potted soybean plants, demanded more effort, space and time than the used in this work.

As observed in the previous study, oviposition starts with high numbers and, then, decreased gradually from the third week on to lower levels. This is an important biological aspect in mass rearing insects (Boller, 1972). Daily egg production from five cages ranged from 1,371 to 2,174 (Figure 2). Over the course of 2.5 months, a total of 36,731 eggs was produced, of which $50.3 \%$ were used to rear egg parasitoids $T$. podisi; the remaining eggs were used in laboratory experiments and to maintain the colony. Of the initial cohort, about $30 \%$ of females lived up 35 days and were able to produce progenies.

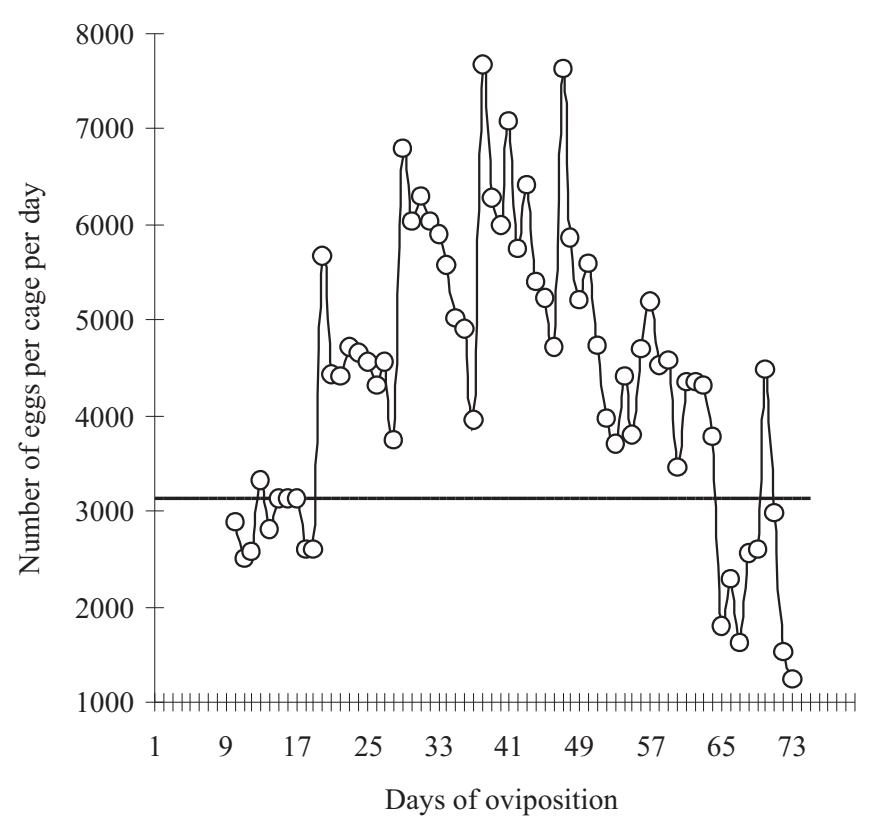

Figure 2. Egg production of Euschistus heros (open circles), and the mean number of eggs used to rear the egg parasitoid Telenomus podisi (straight line) in laboratory, after improving the rearing technique.
Therefore, the discard age for optimizing the colony was around 35 days, when approximately $70 \%$ of total eggs were laid. Peres \& Corrêa-Ferreira (2001) reported for E. heros a longer period of maximum oviposition (from the third to the fifth week), and suggested that insects should be kept in cages until the first seven weeks of oviposition. In contrast, adults of $N$. viridula should be discarded after the third week of oviposition (CorrêaFerreira \& Moscardi, 1996).

With this technique using 35 cages, a production of about 313,275 eggs per month can be obtained. Considering the data on parasitism, emergence and sex ratio of $T$. basalis and $T$. podisi from E. heros eggs (Peres \& Corrêa Ferreira, 2004), and the recommended liberation of 5,000 wasps ha $^{-1}$ to control stink bugs on soybean (Corrêa-Ferreira, 2002), this colony can supply parasitoids to crop areas of 30-35 ha per month.

In summary, this study highlights the importance of considering the effect of egg and adult density on the performance of mass rearing of E. heros. The procedures of the improved technique are: eggs are placed in groups of 100 per Petri dish; nymphs reaching the third instar are transferred to adult rearing cages; newly molted adults are separated and placed in groups of 100 couples per cage, considered day 0 (zero); around day tenth, the oviposition will start, and another group of insects will be formed; every ten days groups of cages are formed to maintain a constant egg production; from day tenth to $30^{\text {th }}$ (period of maximum egg production) eggs are collected in each group formed; insects are discarded after 35 days of life.

\section{Conclusions}

1. High density, in the rearing units, affects survivorship of nymphs and egg production of Euschistus heros in laboratory.

2. Densities of 100 eggs per Petri dish ( $9 \mathrm{~cm}$ diameter) and 100 couples per cage $(900 \mathrm{~mL})$ are the best conditions for rearing $E$. heros.

\section{Acknowledgements}

To Conselho Nacional de Desenvolvimento Científico e Tecnológico and to Fundação de Apoio à Pesquisa do Distrito Federal, for financial support; to Diva Tiburcio Ribeiro and Helio Moreira dos Santos, for their assistance with the insect colony and maintenance. 


\section{References}

BAUERFEIND, S.S.; FISCHER, K. Effects of food stress and density in different life stages on reproduction in a butterfly. Oikos, v.111, p.514-524, 2005.

BOLLER, E. Behavioral aspects of mass-rearing of insects. Entomophaga, v.17, p.9-25, 1972.

BORGES, M.; COLAZZA, S.; RAMIREZ-LUCAS, L.P.; CHAUHAN, K.R.; MORAES, M.C.B.; ALDRICH, J.R. Kairomonal effect of walking traces from Euschistus heros (Heteroptera: Scelionidae) on two strains of Telenomus podisi (Hymenoptera: Scelionidae). Physiological Entomology, v.28, p.349-355, 2003.

BORGES, M.; COSTA, M.L.M.; SUJII, E.R.; MEDEIROS, M.A.G.; REDÍGOLO, G.F.; RESCK, I.S.; VILELA, E.F. Semiochemical and physical stimuli involved in host recognition by Telenomus podisi (Hymenoptera: Scelionidae) towards Euschistus heros (Heteroptera: Pentatomidae). Physiological Entomology, v.24, p.227-233, 1999.

CALTAGIRONE, L.E. Landmark examples in classical biological control. Annual Review of Entomology, v.26, p.213-232, 1981.

CIVIDANES, F.J.; PARRA, J.R.P. Zoneamento ecológico de Nezara viridula (L.), Piezodorus guildinii (West.) e Euschistus heros (Fabr.) (Heteroptera: Pentatomidae) em quatro Estados produtores de soja no Brasil. Anais da Sociedade Entomológica do Brasil, v.23, p.219-226, 1994.

CLARKE, A.R. The control of Nezara viridula L. with introduced egg parasitoids in Australia. A review of a landmark example of classical biological control. Australian Journal of Agricultural Research, v.41, p.1127-1146, 1990.

CORRÊA-FERREIRA, B.S. Trissolcus basalis para o controle de percevejos da soja. In: PARRA, J.R.P.; BOTELHO, P.S.; CORRÊA-FERREIRA, B.S.; BENTO, J.M.S. (Ed.). Controle biológico no Brasil: parasitóides e predadores. São Paulo: Manole, 2002. p.449-476.

CORRÊA-FERREIRA, B.S.; MOSCARDI, F. Biological control of soybean stink bug by inoculative releases of Trissolcus basalis. Entomologia Experimentalis Applicata, v.79, p.1-7, 1996.

CORRÊA-FERREIRA, B.S.; MOSCARDI, F. Seasonal occurrence and host spectrum of egg parasitoids associated with soybean stink bugs. Biological Control, v.5, p.196-202, 1995.

COSTA, M.L.M.; BORGES, M.; VILELA, E.F. Biologia reprodutiva de Euschistus heros (F.) (Heteroptera: Pentatomidae). Anais da Sociedade Entomológica do Brasil, v.27, p.559-568, 1998.

EHLER, L.E. An evaluation of some natural enemies of Nezara viridula in Northern Califórnia. BioControl, v.47, p.309-325, 2002. FORTES, P.; MAGRO, S.R.; PANIZZI A.R.; PARRA, J.R.P. Development of a dry artificial diet for Nezara viridula (L.) and
Euschistus heros (Fabricius) (Hymenoptera: Pentatomidae). Neotropical Entomology, v.35, p.567-572, 2006.

MOE, S.J.; STENSETH, N.C.; SMITH, R.H. Density dependence in blowfly populations: experimental evaluation of non-parametric time-series modeling. Oikos, v.98, p.523-533, 2002.

PANIZZI, A.R.; OLIVEIRA, E.D.M. Performance and seasonal abundance of the Neotropical brown stink bug, Euschistus heros nymphs and adults on a novel food plant (pigeon pea) and soybean. Entomologia Experimentalis et Applicata, v.88, p.169-175, 1998.

PANIZZI, A.R.; PARRA, J.R.P.; SANTOS, C.H.; CARVALHO, D.R. Rearing the Southern green stink bug using an artificial dry diet and an artificial plant. Pesquisa Agropecuária Brasileira, v.35, p.1709-1715, 2000.

PANIZZI, A.R.; VIVAN, L.M. Seasonal abundance of the Neotropical brown stink bug, Euschistus heros, in over wintering sites, and the breaking of dormancy. Entomologia Experimentalis et Applicata, v.82, p.213-217, 1997.

PERES, W.A.A.; CORRÊA-FERREIRA, B.S. Methodology of mass multiplication of Telenomus podisi (Ash.) and Trissolcus basalis (Woll.) (Hymenoptera: Scelionidae) on eggs of Euschistus heros (Fab.) (Hemiptera: Pentatomidae). Neotropical Entomology, v.33, p.457462, 2004.

PERES, W.A.A.; CORRÊA-FERREIRA, B.S. Nymphal and adult performance of Euschistus heros (Fabr.) (Hemiptera: Pentatomidae), as a potential alternative host for egg parasitoids multiplication. Neotropical Entomology, v.30, p.535-540, 2001.

SATO, T.; SHINKAJI, N.; AMANO, H. Effects of density on larval survivorship and imaginal fecundity of Dacne picta (Coleoptera: Erotylidae). Applied Entomology and Zoology, v.39, p.591-596, 2004.

SHIMOJI, Y.; YAMAGISH, M. Reducing rearing cost and increasing survival rate of West Indian sweet potato weevil, Euscepes postfasciatus (Fairmaire) (Coleoptera, Curculionidae) on artificial larval diet. Applied Entomology and Zoology, v.39, p.41-47, 2004.

SILVA, C.C.; MORAES, M.C.B.; LAUMANN, R.A.; BORGES, M. Sensory response of the egg parasitoid Telenomus podisi to stimuli from the bug Euschistus heros. Pesquisa Agropecuária Brasileira, v.41, p.1093-1098, 2006.

SOSA-GOMEZ, D.R.; CORSO, I.C.; MORALES, L. Insecticide resistance to endosulfan, monocrotophos and metamidophos in the Neotropical brown stink bug, Euschistus heros (F.). Neotropical Entomology, v.36, p.317-320, 2001.

SUJII, E.R.; COSTA, M.L.M.; PIRES, C.S.S.; COLAZZA, S.; BORGES, M. Inter and intra-guild interactions in egg parasitoid species of the soybean stink bug complex. Pesquisa Agropecuária Brasileira, v.37, p.1541-1549, 2002. 